\title{
DIFICULDADES NA AQUISIÇÃO DE LÍNGUA ESTRANGEIRA: ALGUMAS QUESTÕES SOBRE O CASO DE UMA IMIGRANTE BRASILEIRA NOS ESTADOS UNIDOS
}

\author{
DIFFICULTIES IN FOREIGN LANGUAGE ACQUISITION: SOME QUESTIONS ABOUT \\ THE CASE OF A BRAZILIAN IMMIGRANT IN THE UNITED STATES
}

\author{
Elisabeth Cavalcanti Coelho ${ }^{1}$ \\ Maria de Fátima Vilar de Melo \\ Glória Maria Monteiro de Carvalho ${ }^{3}$
}

\begin{abstract}
RESUMO: O presente artigo é oriundo de uma pesquisa, realizada sob a forma de um estudo de caso, que investigou a relação conflituosa de uma brasileira imigrante com a língua inglesa, oficial do país adotado. Nesse sentido, visa discutir questões concernentes às incidências do medo da separação da língua materna sobre o processo de se tornar falante em uma língua estrangeira em situação de imersão. Os fundamentos teóricos consistem em trabalhos realizados nos campos da psicanálise e da linguística cujos autores, em sua maioria, consideram a interface entre a linguística e a psicanálise. São trabalhos que se debruçam sobre a aquisição de língua estrangeira destacando o incontestável laço que cada sujeito mantém com a língua materna, constitutiva do sujeito. O corpus da pesquisa foi constituído por entrevistas semiestruturadas via Skype e WhatsApp, cujas questões versavam sobre essa relação, mais especialmente sobre dificuldades enfrentadas por Celina na relação com a língua inglesa. De um modo geral, a discussão foi apoiada na psicanálise de Freud e Lacan, bem como em autores que nela se ancoram, e teve como eixo o medo (da separação) que estaria ligado ao recalque (e ao retorno do recalcado) no que toca a relação entre língua materna e língua estrangeira. Os resultados revelam a insistência do significante medo, que marca a dificuldade de separação da língua materna, além de contradições, confusão pronominal e predominância de discurso direto. São aspectos que convergem para a indicação de um retorno da angústia e do medo gerados por separações vividas no processo de aquisição da língua materna e que produzem efeitos na relação com a língua estrangeira.
\end{abstract}

Palavras-chave: Língua materna; língua estrangeira; imigrante; medo.

ABSTRACT: This article comes from a research, conducted in the form of a case study, which investigated the conflicting relationship between a Brazilian immigrant and the official language of the current country. Therefore, it aims to discuss issues concerning the incidences of the fear of separation of the mother tongue on the process of becoming a speaker in a foreign language in an immersion situation. The theoretical constructs underlying the text are supported by authors who consider the interface between linguistics and psychoanalysis. These are works that focus on the acquisition of foreign

\footnotetext{
${ }^{1}$ Fonoaudióloga, Mestre em Distúrbios da Comunicação pela PUC-SP, Doutoranda em Ciências da Linguagem na Universidade Católica de Pernambuco-UNICAP.

${ }^{2}$ Psicóloga, Doutora em Psicologia pela Université René Descartes - Paris V. Professora do Programa de PósGraduação em Ciências da Linguagem da Universidade Católica de Pernambuco-UNICAP.

3 Psicóloga, Pós-Doutora em Aquisição de Linguagem pela Universidade Estadual de Campinas-UNICAMP. Professora do Programa de Pós-Graduação em Ciências da Linguagem da Universidade Católica de PernambucoUNICAP.
} 
language highlighting the undeniable bond that each subject maintains with the mother tongue, constitutive of the subject. The corpus of the research consisted of semi structured interviews via Skype and WhatsApp, whose questions dealt with this relationship, more especially about difficulties faced by Celina concerning the English language. In general, the discussion was supported by Freud and Lacan's psychoanalysis, as well as by authors who are anchored in it, and had as its axis the fear (of separation) that would be linked to the repression (and the return of the repressed) regarding the relationship between mother tongue and foreign language. The results reveal the persistence of significant fear, which marks the difficulty of separating from her mother tongue, as well as contradictions, confusion in using pronouns, and predominance of direct speech. These aspects converge to indicate a return of both anguish and fear engendered by separations experienced in the process of acquisition of one's mother tongue, which generate aftereffects on the relationship with a foreign language.

Keywords: Mother tongue; foreign language; immigrant; fear.

\section{Introdução}

Segundo Revuz (2016), uma porcentagem bastante reduzida dos sujeitos que se propõem a aprender uma língua estrangeira chega a ter com essa língua, de fato, uma relação que os levem a entender, ler, falar e escrever sem maiores dificuldades. Na direção oposta, porém, essa autora refere-se a alunos que, independentemente das condições em que se encontram, do método ou da abordagem utilizada, destacam-se de forma brilhante no contato com a nova língua. Esses fatos remetem-nos a Gasparini (2010a), ao destacar a relação com a língua estrangeira como apoiada nos trilhos da língua materna, que se configura como singular e única.

Ao fazer uma rápida revisão nesse campo de conhecimento, observa-se que a maioria dos estudos concebe essa aquisição como um processo comum de ensino e aprendizagem restringindo-se, geralmente, a enfocar ora a didática do professor, ora as capacidades necessárias aos alunos, bem como as estratégias por esses empregadas, para serem considerados falantes em outra língua ou em outras línguas. Nesse campo, propõe-se que existem duas situações: “aprender" no país da língua e aprender no país de origem ou em que residem. A primeira é reconhecida como uma situação de imersão na língua, porém ela abriga duas situações que comportam elementos claramente diferentes: a) a primeira diz respeito a pessoas que vão morar, por um período de duração variada, em um país no intuito de aprender a língua; b) a segunda concerne às pessoas que, por motivos diversos, deixaram seu país de origem, tornando-se imigrantes. As situações de imersão são consideradas as mais propícias para a realização dessa aquisição ou aprendizagem, como geralmente é assumido pela maior parte dos pesquisadores, pela intensiva exposição à língua em ambiente natural, tendo assim o contexto a seu favor. Porém, a despeito de residir no país, não é pequeno o número de pessoas que não chegam a se tornar falantes na língua oficial do país, chamando atenção no caso de imigração cuja residência não tem o caráter transitório típico das situações de intercâmbio. Importa assinalar aqui que a situação de imigração implica abrir mão da sua pátria mãe, significante que destacamos por considerarmos que ele faz coro com língua materna. Essa situação tem sido objeto de muitos estudos dos quais ressaltamos os estudos realizados na psicanálise, tendo como um dos pontos de origem o trabalho realizado por Melman (1992). Sobre isso, nas redes sociais, é comum a 
identificação de sujeitos que se referem a não saber lidar com a nova língua, apresentando, então, sérias dificuldades daí decorrentes, no seu cotidiano. Convém notar que essa nova língua será o ponto de partida para a assunção de um papel ativo na sociedade: por meio dela é que serão estabelecidos os vínculos sociais, as amizades, a escolarização, a profissionalização. Nessa perspectiva, nossa questão básica diz respeito a dificuldades envolvidas na aquisição de uma língua estrangeira, considerando a situação de imersão por imigração, tida como favorável.

Independentemente das condições de aquisição, de acordo com Revuz (2016), aprender outra língua torna-se um ato delicado na medida em que envolve a base da estruturação psíquica do sujeito e traz à tona a experiência com a língua materna, que interfere na nova aquisição. Assumimos, então, a proposta dessa autora, fundada na psicanálise lacaniana. É digno de nota que, conforme Vilar de Melo (2015), esta proposta juntamente com o livro de Melman acima citado, encontra-se na origem de uma nova abordagem de aquisição de uma língua estrangeira, abordagem que faz valer o diálogo entre a linguística e a psicanálise; a título de exemplificar, citamos os trabalhos realizados por Serrani-Infante (2016), Moraes (1999), Coracini (2003, 2007), Gasparini (2010a, 2010b), entre outros. Esses trabalhos investigam a aquisição da língua estrangeira, destacando a relação com a língua materna concebida como língua fundadora, na medida em que constitui o sujeito.

Tendo em vista essa relação, assumimos também que, falar outra língua requer do sujeito certa dose de liberdade em relação à língua dita materna, o que implica a operação de separação da criança de sua mãe. Nesse aspecto, ancoramo-nos em Freud ([1856-1939] 2018), para quem a ideia infantil de separação liga-se ao afeto de medo, sendo, então, submetida à operação de recalque. No entanto, uma vez recalcada, pode retornar em determinadas situações vividas pelo sujeito, trazendo consigo o medo a que se liga.

A partir das propostas teóricas de que lançamos mão, consideramos que o processo de tornar-se falante de uma língua estrangeira seria uma situação onde esse recalcado (a separação infantil) poderia retornar, gerando dificuldades que se tornariam mais visíveis quando se trata das condições favoráveis de imersão e, sobretudo, de imigração.

Neste artigo, nosso objetivo consiste em discutir questões concernentes às incidências do medo da separação da língua materna sobre o processo de se tornar falante em uma língua estrangeira em uma situação de imersão. Como fundamento empírico às questões levantadas, serão apresentados e discutidos recortes do discurso de uma brasileira residente no exterior sobre suas dificuldades com a língua inglesa, discurso que foi obtido por meio de entrevistas semiestruturadas via Skype e WhatsApp.

\section{Relação entre língua estrangeira e língua materna}

De acordo com Melman (1992, p. 33), a língua materna é aquela que traz à lembrança a figura que colocou a criança no jogo de significantes, introduzindo-a na fala. Nessa perspectiva, o autor a define como a língua na qual a mãe, objeto primeiro e privilegiado de desejo, foi interditada na sua relação com seu filho ou sua filha e, neste sentido, é a língua do desejo. Em suas palavras, língua materna "[...] é aquela na qual funcionou para o pequeno falante, para o 
sujeito que a articula, o interdito de sua mãe. E a chamamos 'língua materna' porque é inteiramente organizada por este interdito [...]”. (MELMAN, 1992, p. 44; ênfase do autor)

Para Milner (2018), a língua inicial é incomparável em relação às demais, possuindo estatuto de uma língua particular. Nessa direção, Gasparini concebe a língua materna como aquela que:

[...] apresenta um estatuto especial para o sujeito, não podendo ser equiparada a nenhuma outra língua, qualquer que seja, por ser carregada de predicados e afetos, e por estar em jogo desde o momento mítico de seu surgimento (GASPARINI, 2010a, p. 4).

Segundo essa autora, cujo trabalho ancora-se no de Revuz, a língua materna deve ser vista como a mais primitiva e singular inscrição do simbólico que afeta o corpo do sujeito, entendido como corpo pulsional e, assim, "ela deve aceder à posição fundamental de línguacausa do sujeito, língua nele encarnada, possibilidade de sua existência e de sua emergência" (GASPARINI, 2010b, p. 43). Nessa perspectiva, assume que toda aprendizagem que se refere à função simbólica se efetua a partir de inscrições feitas por essa língua. Essas ideias vem corroborar a posição de Revuz, que destaca o caráter inaugural da língua materna para o advento do sujeito, na medida em que ela é "o material fundador de nosso psiquismo e de nossa vida relacional” (REVUZ, 2016, p. 217).

A propósito da relação entre língua materna e língua estrangeira, Melman (1992) considera-a como uma questão inquietante. Segundo sua proposta, há algo da ordem do afetivo que perpassa essa relação, na medida em que a língua materna se vincula à lembrança do vivido, por ser a língua na qual o sujeito foi introduzido na fala. Essa posição é consoante a de Revuz (2016) que destacou o aspecto singular dessa relação e reconheceu a língua estrangeira como um objeto complexo que exige do sujeito, além do conhecimento intelectual, uma prática de expressão que faz emergir a sua forma de relacionamento no mundo e um trabalho do corpo que envolve o aparelho fonador, levantando como hipótese para o insucesso a incapacidade de unir essas dimensões. Para essa autora, o trabalho de corpo requer flexibilidade para lidar com ritmos, sons e curvas entoacionais, além da memorização das estruturas linguísticas. Coloca a autora:

Toda tentativa para aprender outra língua vem perturbar, questionar, modificar aquilo que está inscrito em nós com as palavras dessa primeira língua. Muito antes de ser objeto de conhecimento, a língua é o material fundador de nosso psiquismo e de nossa vida relacional (REVUZ, 2016, p. 217).

Em outras palavras, Revuz (2016) afirma que o sujeito constituído pela linguagem traz consigo uma história que se relaciona com a língua que o inscreveu, o que vai interferir na forma de se relacionar com a língua estrangeira. Nesse sentido, ao destacar os efeitos que uma língua estrangeira pode produzir sobre um sujeito, Coracini (2007, p. 152) escreve que:

Ainda que seja aprendida com um fim meramente utilitarista, ela traz sempre consigo consequências profundas e indeléveis para a constituição do sujeito: 
serão sempre outras vozes, outras culturas, outra maneira de organizar o pensamento, outro modo de ver o mundo e o outro [...].

Nessa direção, Serrani-Infante (2016) propõe que independentemente da forma como se dá o acesso à língua estrangeira, é o processo de tomada da palavra que está em cena e, paralelamente, a tomada do sujeito pela língua. Assim, aqueles tidos como mais presos na sua língua inaugural poderiam apresentar algum tipo de resistência inconsciente, para o afastamento necessário ao lidar com um novo tipo de funcionamento linguístico, tornando o processo dificultoso e decepcionante. Contrariamente, sujeitos tidos como menos aprisionados na língua materna viveriam o enfrentamento de outra língua de forma menos turbulenta. Corroborando essa ideia, Gasparini (2010b, p. 83) diz que "as reverberações dos elementos materiais e afetivos da língua materna em uma outra, estrangeira, dependem do posicionamento subjetivo em relação à língua-causa”, e segue afirmando que, para os sujeitos menos ancorados na língua materna, a língua estrangeira não seria vivida como uma ruptura ou como um processo doloroso.

Com fundamento no que foi posto, destacamos que, em virtude da relação com a língua materna, os autores aqui abordados concebem a aquisição da língua estrangeira como um processo singular, delicado, inquietante, complexo, do que se poderia inferir que a aquisição da língua materna não apresentaria essas marcas. No entanto, como mostra Lemos (2007, p. 121) com base nos construtos da psicanálise, a constituição da criança como falante, ou seja, a sua captura pela língua implica um "conflito a esperar do embate entre heterogêneos - corpo e linguagem [...]”. Nessa perspectiva, fazendo apelo à proposta lacaniana, refere-se a "efeitos e a violência dos mecanismos do significante pelos quais o vivente é capturado e permanece aprisionado, assim como "arrancado de sua imanência vital" (p. 119, ênfase da autora). Como consequência desse conflito, a criança encarna um ponto de angústia que, em virtude de um encobrimento imaginário não é considerado por psicólogos e pedagogos. Segundo essa proposta, em uma posição inicial - denominada espelhamento - a criança incorpora a fala da mãe, sendo as produções verbais infantis constituídas de fragmentos de enunciados maternos, evidenciando uma fala que não se separa da língua materna. No entanto, em uma outra posição, surgem indícios de separação os quais consistem, por exemplo, no aparecimento de erros nas produções infantis. Os erros seriam, portanto, marcas de um distanciamento, de um "movimento de resistência ou até mesmo de separação" da fala do outro (LEMOS, 2007, p.123). Seriam marcas do "corte significante", ou seja, do corte provocado pelos significantes que se inscrevem no corpo da criança, afastando-a, separando-a da mãe e laçando-a no movimento de tomar a palavra. Enfim, esse afastamento, essa separação, na medida em que consiste num conflito, configurando uma situação de perigo, não poderia ocorrer sem angústia, e acrescentamos, sem medo. Revuz (2016) expõe essa ideia de angústia ao se remeter aos efeitos no corpo, quando afirma que:

Começar o estudo de uma língua estrangeira é se colocar em uma situação de não saber absoluto, é retornar ao estágio do infans, do neném que não fala ainda, (re)fazer a experiência da impotência de se fazer entender. [...] é proporcionar uma liberdade esquecida do aparelho fonador, explorar 
movimentos de contração, relaxamento, abertura, fechamento, vibração que produzem, ao mesmo tempo que os sons, muitas sensações surpreendentes no plano dessa região bucal, tão importante no corpo erógeno (REVUZ, 2016, p. 221).

Ancoradas no que foi posto, assumimos que a aquisição da língua materna consiste também em um processo singular, delicado, inquietante, complexo, adjetivos que os autores citados atribuem à aquisição de língua estrangeira. $\mathrm{O}$ estudo de caso que deu origem a este artigo trouxe à luz a vinculação entre dificuldades em tornar-se falante em uma língua estrangeira e o laço aprisionante com a língua materna. Nessa perspectiva, reafirmamos, então, que a separação pode estar ligada ao medo - que abordaremos a seguir, na concepção psicanalítica - e se faria presente, embora de modos diferentes, no processo de tornar-se falante, quer da língua materna, quer de uma língua estrangeira.

\section{Sobre o medo da separação}

Para Freud ([1856-1939] 2018), é difícil compreender o medo, e a tentativa de atingir a sua essência insere-se em um caminho sinuoso. Na realidade, nesse caminho formado pelas escolhas freudianas sobre o tema, deparamo-nos com contradições - apontadas pelo psicanalista - oscilações, idas e vindas, mudanças conceituais, o que indica a dificuldade destacada e o cuidado do autor ao lidar com essa dificuldade.

$\mathrm{Na}$ teoria freudiana, medo reflete um estado afetivo, de caráter desprazeroso evidente, mas que não se esgota em si mesmo, considerando não ser possível afirmar que todo ato desprazeroso seja medo. Nos casos do luto, das tensões e da dor, por exemplo, o desprazer não é medo. Freud ([1856-1939] 2018) atém-se a algumas situações de manifestação do medo infantil: o estar só; estar no escuro, e; se deparar com um estranho no lugar que geralmente é ocupado pela mãe. São situações que se traduzem de uma mesma forma e revelam o sentimento de falta da pessoa amada/ansiada. Afirma, então, que "[...] o medo aparece como reação à falta que se sente do objeto, e impõe-se a nós as analogias de que também o medo da castração tem por conteúdo a separação de um objeto muito estimado e que o medo mais originário [...] surgiu quando se foi separado da mãe" (FREUD [1856-1939] 2018, p. 128).

O autor propõe que o medo gerado no lactente pela percepção da ausência da mãe já é entendido como um primeiro grande progresso, ao configurar-se como uma mudança que está relacionada aos cuidados com a autoconservação, mudança essa que "inclui ao mesmo tempo a passagem do ressurgimento automático e involuntário do medo à sua reprodução intencional como sinal de perigo" (FREUD [1856-1939] 2018, p. 129-130). Assim, o medo do lactente, tanto como fenômeno automático quanto como sinalizador de perigo, revela a condição vivida por ele, que é de desamparo psíquico decorrente do próprio desamparo biológico. Ressaltamos, no entanto, que em ambos os casos o que emerge é a separação da mãe.

$\mathrm{Na}$ fase fálica, o medo da perda do objeto se transformará no medo da castração, que ainda é um medo da separação, mas separação dos genitais. $O$ passo seguinte traz o medo relacionado ao poder do supereu que, posteriormente, adquire sua dimensão social como medo de ser excluído do grupo, emergindo no momento em que a criança já está mais independente. 
Apesar de suas peculiaridades, as situações de perigo, segundo Freud ([1856-1939] 2018), de um modo geral apontam para uma perda, uma separação.

Retomando as colocações de Lemos (2007), não é demais repetir que assumimos a proposta de que a separação da figura materna, concebida como uma situação de conflito, ou de perigo, juntamente com a angústia e o medo dela advindos, é vivenciada pelo infans, em sua constituição como falante. No entanto, em outro momento essa vivência é "deixada de lado", ou melhor, é recalcada, podendo retornar em situações que, de algum modo, dela se aproximem. O que vem a ser o recalque para Freud?

Verdrängung é o termo em alemão que Hanns (1996) em seu Dicionário comentado do alemão de Freud afirma ser traduzido por "recalque" ou "repressão", podendo apresentar significados como empurrar para o lado, desalojar, incômodo, sufoco. Refere-se ao material mantido no espaço intrapsíquico, mas pelo incômodo que gera é conduzido pelo sujeito para fora da consciência. Esse material permanece, porém, no sujeito, mas mantém a busca por caminhos que possam trazê-lo de volta, o que obriga o sujeito a canalizar energia a fim de mantê-lo fora da cena. A função do recalque, explica Hans (1996), seria gerar contrainvestimentos, objetivando a manutenção desse material recalcado no inconsciente. A teoria do recalque é tida pelo próprio Freud ([1915] 2004) como a pedra angular sobre a qual se estrutura a psicanálise. Ao discorrer sobre seu mecanismo, afirma ser na prática da psicanálise que se pode constatar a possibilidade de compreender que o mecanismo do recalque, como defesa, não existe desde sempre, havendo como condição para o seu surgimento o estabelecimento da separação entre a atividade psíquica consciente e inconsciente.

Garcia-Roza (2009) fala sobre o recalque primário como as primeiras marcas psíquicas advindas de experiências que, por serem bastante intensas, jamais chegam à consciência. Da ordem do irrepresentável, o recalque primário funciona como polo de atração para recalques posteriores. No recalque secundário, os conteúdos condenados pelo superego são remetidos para o inconsciente, e Freud ([1915] 2004, p. 179) afirma que esse tempo "refere-se a representações derivadas do representante recalcado ou ainda àquelas cadeias de pensamentos que, provindo de outros lugares acabam estabelecendo ligações [...] associativas com esse representante [...]." São associações que levam ao mesmo destino do recalcado original.

Como apontado anteriormente, esse retorno acontecerá em situações que tenham aproximação com o conteúdo recalcado, e podemos dizer que uma dessas situações seria a aquisição de uma língua estrangeira que requer do sujeito sair do domínio exclusivo da língua materna, o que significa uma separação dessa língua, na medida em que implica uma mudança de posição de falante apenas da língua que o constituiu para a de falante também de outra língua.

\section{Recortes do discurso de Celina: uma tentativa de discussão}

A pesquisa que está na base deste artigo $^{4}$ foi realizada nos moldes de orientação qualitativa, portanto sem o interesse em apresentar algum tipo de representatividade numérica,

\footnotetext{
${ }^{4}$ Trata-se de pesquisa realizada como parte da Tese de Doutorado (COELHO, 2019) desenvolvida no Programa de Pós-Graduação em Ciências da Linguagem da Universidade Católica de Pernambuco - UNICAP, cujo projeto foi
} 
mas sim em aprofundar aspectos revelados a partir da relação do sujeito com a língua estrangeira, tendo em vista o objetivo proposto.

Assim, considerando o objetivo deste artigo, apresentamos alguns recortes do relato de um caso, acreditando que possam, de algum modo, iluminar questões que emergem do discurso de um sujeito no processo de tornar-se falante de uma língua estrangeira. Trata-se de Celina, sujeito selecionado considerando o longo período em que vivencia os embates decorrentes do enfrentamento em relação à língua estrangeira. $\mathrm{O}$ corpus da pesquisa foi composto por meio de entrevista semiestruturada, via Skype, em janeiro de 2018, tendo as seguintes perguntas-eixo: Como se deu sua mudança para (local)? Cotidiano com a língua (trabalho, lazer, vida social etc...)? O que você faz diante de dificuldades para falar a lingua local? Procurou algum tipo de ajuda? Quais? Fala outras línguas? Estabelece alguma relação com a lingua local? Em que aspectos você situa a dificuldade com a lingua? Em diferentes contextos você sente diferenças em falar a língua local? Como se deu o primeiro contato com essa lingua? Quando? Em que momentos você percebe que as dificuldades diminuem?

Inicialmente, foi solicitado que a entrevistada falasse sobre como se deu a mudança de residência para o exterior, sendo permitido que discorresse livremente sobre o assunto, com pouca interferência da pesquisadora, que interveio nos momentos oportunos para a introdução das demais questões. Posteriormente, pela necessidade de complementação de alguns dados, foram mantidos dois outros contatos via áudio pelo WhatsApp, em outubro de 2018 e julho de 2019. Os recortes ${ }^{5}$ que constituem a base empírica da proposta deste artigo referem-se aos ditos da participante acerca de sua experiência com a língua estrangeira e destinam-se, sobretudo, a fundamentar o levantamento de questões sobre essa experiência, conforme está expresso no título. Para a presente discussão, trazemos esses ditos, a partir de significantes que se destacam pela repetição e/ou, pela contradição, produzindo, naqueles que os escutam, um efeito de estranhamento. Antes de adentrar especificamente a discussão a que nos propomos, torna-se importante situar alguns pontos da história de Celina, lembrando que estamos tratando, aqui, da relação de um sujeito com a língua estrangeira, uma relação perpassada por dificuldades.

Celina é profissional da área de saúde, aposentada por invalidez devido à obesidade. Tem 57 anos e, viúva, casou-se com um americano que conheceu pela internet e com o qual se comunicava com auxílio do Google tradutor. O namoro durou mais de um ano nessas condições, até que resolveram se conhecer pessoalmente e decidiram casar-se. Após o casamento, mudou-se definitivamente para os Estados Unidos e, à época da entrevista, já residia naquele país há mais de seis anos, ainda com dificuldades importantes em relação à língua local. Fez várias tentativas de estudar inglês em cursos locais, bem como com professora particular brasileira, mas sempre desistia. Frequenta igreja junto com o marido, onde participa de atividades e diz ter um círculo de amizades composto tanto por americanos, quanto por brasileiros. Relata que, atualmente, já consegue falar em inglês com o marido, bem como em

submetido ao Comitê de Ética em Pesquisa e aprovado sob o CAAE 791250.17.0.0000.5206. Em virtude do espaço de que dispomos em um artigo, os recortes aqui discutidos representam, apenas, uma pequena parte do corpus discursivo de que dispomos.

${ }^{5}$ Convém notar que a apresentação desses recortes não segue uma ordem cronológica dos acontecimentos vividos pela participante do estudo. 
diversas situações do cotidiano, embora afirme não ter confiança no uso da língua. Diante disso, mantém o recurso da escrita e do Google tradutor.

\subsection{O medo de falar}

Celina conta-nos que fez formação em enfermagem, trabalhando por um longo tempo na área:

[...] No Brasil eu sou auxiliar de enfermagem na área psiquiátrica. Trabalhei 13 anos nessa área.

Além disso, afirma:

[...] Eu sou o cabeça da casa! Meu marido me dá o dinheiro e eu faço as coisas, eu que pago tudo, eu que vejo tudo, eu que faço lista, eu vou às compras... e eu que dou o dinheiro pra ele, e assim vai.

Refletindo sobre esse recorte, somos levadas a acreditar que Celina tem habilidades, ou seja, formou-se e trabalhou na área, administra a casa em todos os aspectos, inclusive o financeiro, o que nos dá indicações de que não existem obstáculos gerais diante da vida que possam justificar sua barreira com a língua estrangeira.

Falar outra língua nos faz pensar, ainda, nas oportunidades vivenciadas. Celina afirma não ter sido possível, na infância, estar em uma escola específica para o ensino de línguas; no entanto, ao mudar-se para outro país, as oportunidades deveriam estar presentes no seu dia a dia, principalmente considerando o fato de estar casada com cidadão dos Estados Unidos. Assim, sem dificuldades significativas para conduzir sua vida e tendo oportunidades para vivenciar a língua estrangeira no dia a dia, como entender suas dificuldades no processo de tornar-se falante de outra língua? A fim de abordarmos essa questão, destacaremos alguns significantes que insistiram em nossa escuta do discurso da participante sobre sua dificuldade com a língua estrangeira (o inglês).

Ao nos debruçarmos sobre o que diz Celina, localizamos, como eixo, o significante medo, que se impôs à nossa escuta e do qual partimos para indicar os demais significantes e/ou cadeias de significantes que deslizam e apontam, direta ou indiretamente, em sua direção, como mostram os seguintes fragmentos:

[...] aí eu falo pra ele: toma conta de mim que o meu medo é parar na rua. E não saber falar com a polícia [...]

[...] Tenho muito medo de falar errado na frente dos outros [...]

[...] Mas eu, pela voz da pessoa, eu aprendi escutar a voz, e comecei decorar aquilo tudo que eles falavam, decorar na minha mente, mas eu não soltava a lingua, sabe, eu tenho muito receio de soltar a lingua e ficar dando uma de boba! [...] 
Celina conheceu seu marido, americano, em site da internet. Após certo tempo de namoro, o casal resolve se encontrar, motivo pelo qual ela viaja aos Estados Unidos. Ao chegar, no entanto, pensou:

\section{[...] meu Deus, o que é que eu vou fazer nesse país, eu não falo nada de inglês! [...]}

Ao que parece, há um grande questionamento sobre essa viagem, em função do medo, significante que desliza para a cadeia não falar nada de inglês ou não saber falar. Continuando, o fato de Celina afirmar não falar nada de inglês nos gera estranhamento, uma vez que, no Brasil, o idioma inglês faz parte da grade curricular desde muito cedo, o que indica, de alguma forma, que ela foi exposta a essa língua durante grande período da sua escolarização, não estando, portanto, isenta de algum conhecimento referente à língua inglesa, mesmo que da forma mais básica possível. E segue afirmando:

[...] fiquei hospedada na mesma casa que ele, sem saber falar nada de inglês, quase nada, é o básico que eu tinha assim nada. Eu fui aprendendo com ele mesmo, com as palavras que eu usava no google translate, but (ri), but não (ri), mas aí eu não falava nada, tudo tinha que se entrar no google [...].

Nesse excerto, Celina afirma que, ao chegar aos Estados Unidos, ficou hospedada na casa do namorado, mesmo sem saber falar nada de inglês, dito que, imediatamente, desliza para quase nada e para o básico. No entanto, falar nada contradiz falar quase nada e falar o básico.

Ao aproximar-se o momento do seu retorno ao Brasil, Celina parecia convencida de que, por não falar a língua, seu plano de aprofundar os laços com o namorado e chegar ao casamento não iria adiante. Afirma: acho que não vai rolar nada porque eu acho que... eu não falo inglês. O significante medo ligado à expressão não falar inglês deslizou, então, para a expressão não vai rolar, isto é, o relacionamento não vai adiante. Apesar dessa ideia, ela foi pedida em casamento e casou-se de imediato. Após a lua de mel, retornou ao Brasil apenas para reaver seus pertences pessoais e, na viagem de volta aos Estados Unidos, foi apreendida pela imigração. Ao abordar essa situação, Celina volta a se referir ao sem saber falar inglês, sem saber falar nada, apesar de afirmar: mas fiz tudo sozinha, sem saber falar nada. Na verdade, ela conta com a ajuda de uma policial intérprete que falava português. Outro policial liga para seu marido e ela afirma que como eu não sabia falar inglês eu calculei que ele tivesse falado as coisas, mas ele estava apenas checando suas informações. Passada a situação, ela recorre a um amigo que é comissário de bordo para que ele verifique o que poderia haver de erro em sua documentação. Após analisar os documentos, o amigo percebe uma observação no verso de sua certidão de casamento que enfatiza que ela realmente não poderia ter saído dos Estados Unidos naquele momento. Ao relatar a fala do amigo, ela comete um ato falho:

[...] Celina, está escrito aqui atrás na tua certidão que você tem que ficar, você tem que... você não podia ter saído do Brasil, e você tinha que dar entrada no papel até dia tal [...]. 
Seu ato falho se revela quando ao invés de falar que não poderia ter saído dos Estados Unidos, diz que não poderia ter saído do Brasil. Quando questionada pela pesquisadora, de imediato retomou o dito: Não, do Brasil não! Dos Estados Unidos! Refletindo sobre a que remeteria esse ato falho cometido por Celina podemos apontar para um desejo da ordem do inconsciente, um desejo de aproximar-se, ou melhor, de manter-se no porto seguro proporcionado pela língua materna, revelado quando ela diz: você não podia ter saído do Brasil. $\mathrm{O}$ medo efeito do afastamento, da separação da sua língua fundadora nos remete ao que Lacan (1985) afirma: o sujeito é surpreendido pelo que diz. É o sujeito do inconsciente que o ato falha revela. Podemos, ainda, levantar uma hipótese: se, inconscientemente, ela não poderia ter saído do Brasil, pois isso significaria o afastamento da língua materna. E não é exatamente isso que ocorre em relação à língua estrangeira? Para falar outra língua é preciso haver um corte em relação à língua inaugural. Aqui, nos deparamos com o aprisionamento de Celina em relação a sua língua materna, dificultando o laço com a nova língua.

Celina procura aulas de inglês e chama nossa atenção quando diz não entender como conseguia avançar de nível no inglês:

[...] lá na escola e eu fui passando de nivel, eu não sei, eu não sabendo falar inglês [...] e eu passava de ano. Como é que pode isso? Eu não sei falar inglês! [...]

É importante perceber, nesse recorte, que ela estava se referindo a um momento anterior, passado, pois na ocasião da entrevista não frequentava aulas, mas, ao mesmo tempo, fala como se estivesse se remetendo ao seu momento atual quando insiste: eu não sei falar inglês. Assim, quando se via aprovada nos exames, sempre se surpreendia. Inclusive, ao ouvir de uma professora que ela deveria estar em uma classe mais avançada, Celina fala de forma enfática: Minha senhora, eu não sei falar!

Os significantes referentes ao não saber falar continuam a deslizar em seu discurso:

[...] não consigo falar com essa mulher; eu ainda não falo o suficiente; não consigo falar... direito. Surgem novas cadeias: Ai, hoje em dia, eu tentando, fui na escola, depois eu cansei da escola, eu saí. Não, não consigo falar com essa mulher [...].

Celina refere-se à professora de inglês que falava com sotaque japonês. Afirma desconhecer a nacionalidade da professora, apenas sabia que ela não era americana.

Podemos inferir, então, que, no processo de tornar-se falante de uma língua estrangeira (o inglês), Celina deixa transparecer que é o medo que a acompanha, visto que, ao falar, emerge o inevitável confronto com o não correto. Ela diz :

[...] Difícil? Eu acho que difícil pra mim é... como é que eu vou falar o difícil pra mim? É eles falando comigo e eu não saber falar as coisas corretas. Só isso que me dá medo $[\ldots]$.

A cadeia significante não saber falar desliza para não saber falar correto, colocando em evidência mais uma vez o significante medo. Isso acontece quando se vê em alguma situação na qual precisará falar, como nos momentos em que sai desacompanhada dirigindo seu carro. 
Diante da simples possibilidade de o carro apresentar problemas e de ter que ligar para o reboque, diz:

[...] Meu maior medo é que o carro pare na rua e o guincho reboque. Então eu tenho todos os documentos do carro e tudo o mais, mas eu não vou saber falar com o cara. Aí eu falei pro Harold, pra prevenir, quando eu sair sozinha de carro, esteja atento aos telefones, porque se eu tiver numa enrascada, tipo assim, numa situação difícil, eu vou ligar pra você $[\ldots]$.

Vale salientar que esse recorte refere-se a uma situação vivida por ela poucos meses antes da realização da entrevista feita pela pesquisadora. Assim, mesmo prestes a completar sete anos de residência fora do Brasil, trata-se de um sentimento bastante atual. Destaca-se, aqui, o medo de não saber falar com o funcionário que viria socorrê-la para rebocar o veículo, no caso de vir a apresentar algum problema. Mais uma vez, o medo (de não saber falar) desliza para significantes a ele relacionados (deixar o marido atento aos telefones e pronto para tirá-la de uma situação difícil). De forma recorrente o não saber falar, ligado ao significante medo, evidencia-se quando Celina, por exemplo, afirma:

[...] pra mim o difícil mesmo é falar com eles! Mas agora como eu perdi a vergonha eu falo do meu jeito! Eu perdi. Nada pra mim mais é difícil aqui. [...]

Nesse excerto, uma contradição pode ser indicada, na medida em que Celina expõe seu sentimento de medo, sua dificuldade de falar inglês e, imediatamente, segue dizendo que fala do seu jeito e que nada mais é difícil. A contradição se torna mais visível, ao nos confrontarmos com o seguinte recorte:

[...] Aí comecei a falar, falar, falar, falar, as pessoas me corrigiam, cada dia aprendia mais, e tudo o mais, mas em seis anos de casada eu ainda não falo o suficiente, eu não entendo! Não consigo falar... direito! [...]

Somos, então, tomadas por um efeito de estranhamento, considerando também que, ao relatar uma experiência de troca do carro, diz ter vivido a pior situação diante do não conseguir falar a língua. Salientamos que esse acontecimento (a troca do carro) havia ocorrido há aproximadamente três semanas antes da realização da entrevista, o que confirma o caráter contraditório daquela afirmação. Ressaltamos que a ideia de trocar de carro havia partido de Celina, por reconhecer que ambos (ela e o marido) estavam envelhecendo e precisavam de um carro mais confortável:

[...] Nós fomos tentar trocar agora, maior dificuldade pra entender o cara, né, os termos de finanças, e tarará e como é, como não é.

É possível que essa falta de entendimento tenha ocorrido em função da própria transação (leasing), mas não é isso o que ela diz em primeiro lugar. Ao referir-se à dificuldade como sendo a de entender o cara, em vez da dificuldade de entender as transações financeiras, ela parece atribuir à língua o obstáculo para a compreensão, o que também ocorre pela falta de 
compreensão dos termos de finanças. Diante do que se apresentava naquele momento, sua solução foi solicitar ajuda de uma amiga, Maria, brasileira que fala inglês perfeito e de quem cuidou quando apresentou problemas de saúde. Ela segue:

[...] Aí... o que aconteceu? Eu liguei pra Maria, falei: Maria, pelo amor de Deus, a gente está aqui, tentando trocar o carro, e eu não estou entendendo nadinha [...].

Convém notar que é recorrente o efeito de estranhamento produzido, em nossa escuta, por contradições nos ditos de Celina, como mostram, por exemplo, estes dois segmentos:

[...] mas depois, eles procuraram na cidade [...] e não encontravam ninguém para falar português comigo [...]

[...] E lá dentro da nossa igreja tem uma igreja pra pessoas que falam português, somente português, que não querem ir aos cultos americanos, eu prefiro ir aos cultos americanos $[. .$.

Tais excertos dão-nos indicações de um movimento no sentido de uma aproximação ao familiar da língua materna (não encontravam ninguém para falar português comigo) e, ao mesmo tempo, de um afastamento, isto é, de uma aproximação à língua estrangeira (eu prefiro ir aos cultos americanos).

Por sua vez, parece também importante indicar que, em alguns lugares do discurso de Celina, ocorreu uma confusão, entre os tempos verbais, no passado e no presente. Por exemplo, nos segmentos transcritos antes, sobre o seu desempenho em aulas de inglês: eu passava de ano e, logo após: eu não sei falar inglês; depois eu cansei de ir à escola e, em seguida: Não, não consigo falar com essa mulher.

A partir dos segmentos recortados, destacamos o medo infantil que, na concepção freudiana, liga-se à ideia de afastamento, de separação, de falta. Indagamos se essa ideia de separação ligada ao medo não estaria retornando na relação de Celina com a língua inglesa, emergindo em seu discurso por meio da cadeia significante não saber falar. Para fundamentar a indagação sobre esse retorno, evocamos, então, dos recortes discursivos, as seguintes marcas: a insistência do significante medo e seu deslizamento para outros significantes ou cadeias, como é o caso de "não falo nada de inglês"; o ato falho que poderia estar apontando para o seu desejo de aproximar-se, ou melhor, de manter-se no porto seguro proporcionado pela língua materna, revelado quando diz: você não podia ter saído do Brasil; as contradições que nos causaram estranhamento, como não falar nada da língua inglesa e falar o básico, indicando, ao que parece, uma tensão entre a língua materna e a língua estrangeira isto é, entre aproximação e afastamento na relação entre essas duas línguas. Mas, evocamos, sobretudo, a experiência que a participante relata como sendo a mais difícil: a situação da troca do carro, em que Celina diz a gente está aqui, mas segue seu discurso com e eu não estou entendendo nadinha... O marido é americano, fala inglês, está com ela, o que nos causa um forte efeito de estranhamento e nos leva a questionar: por que parece tão desamparada? 
Ainda com Freud ([1856-1939] 2018), o sofrimento de Celina pode apontar para uma experiência de ausência do outro: mesmo estando o marido ao seu lado, fala como se ele não estivesse presente, ou estivesse apenas como presença física, pois diz a gente está. E continua:

\section{[...] Como eu não entendia nada, eu fiquei nervosa eu falei: Maria, me salva! [...].}

Maria é chamada para salvá-la e não para salvá-los! Assim, ao falar como se estivesse, de fato, sem apoio, torna ausente o marido americano e convoca a amiga brasileira, buscando, talvez, um porto seguro. Lembremos que o psicanalista aborda o medo como efeito da percepção, pela criança, do afastamento, da ausência de vários tipos na dependência do momento em que se encontra em sua constituição psíquica. Perguntamos: apesar de estar acompanhada pelo marido, Celina não estaria vivendo a ausência, a separação, o que sinalizaria para uma situação de perigo e a remeteria ao medo que se tornou mais visível quando exclamou: me salva!?

A situação foi bastante aflitiva para ela, como afirma nos recortes que se seguem:

[...] A situação foi essa, que eu não entendia nada que o cara falava, não tinha ninguém que falasse espanhol, eu falei: caramba, o que é que é isso? Eu fiquei aflita... nem na imigração eu fiquei nervosa como esse rapaz me deixou na agência de automóveis.

[...] A compra do carro foi o que eu mais fiquei atordoada, fiquei com dor de cabeça e tive até, inclusive, uma afta na minha boca, do lado de fora, coisa feia, estourou do lado de fora. Fiquei mal com essa coisa de trocar o carro. Como eu não entendia nada, eu fiquei nervosa [...].

Trata-se de uma situação que chegou ao ponto de afetá-la no corpo, o que convoca Revuz (2016), para quem o encontro de uma língua com outra nunca será insignificante para o sujeito e, muitas vezes, terá lugar diante de grande sofrimento psíquico e desconforto. $\mathrm{O}$ desconforto de Celina revela-se, então, num corpo que sofre.

\subsection{Questões levantadas pelo uso dos pronomes pessoais}

Abordaremos os pronomes pessoais como mais um fundamento à questão do medo que se ligaria ao retorno do recalcado, no que toca a relação entre língua materna e língua estrangeira.

Nos fragmentos que se seguem, o uso dos pronomes também causa estranhamento, não somente pela repetição, mas também, e sobretudo, pelas trocas e hesitações que ocorrem em alguns momentos, merecendo destaque. Celina usa ele falou, eu falei..., eu falei... ele falou...

[...] Aí depois disso tudo ele pegou, quando eu ia embora, no meio da semana que eu ia embora, ele falou assim pra mim... eu falei assim...

[...] Aí depois eu acabei de ler, sentei na mesa pra tomarmos o café e ele falou assim pra mim: você leu tudo? Eu falei: sim. E ele falou assim: o que é que você resolveu? Né? Aí eu falei eu falei, falei pra ele eu não vou, eu, eu, eu não... Não, eu falei assim: 
quando você me dá a resposta? Aí ele falou assim, eu falei assim: não, não vou aceitar. Ele... por quê? [...]

Esse recorte aponta para uma confusão pronominal, pois Celina se remete a uma pergunta feita pelo namorado: foi ele quem perguntou sobre a resposta ao pedido de casamento, e não ela. No entanto, afirma: Não, eu falei assim: quando você me dá a resposta? Essa confusão no uso dos pronomes aparece também no momento em que Celina fala sobre ter perdido o voo ao ficar retida pela imigração:

[...] E ele falou assim... ele apertou a minha mão: seja bem-vinda. Eu falei: ai meu Deus! Vou te dar outra passagem, você vai embarcar agora, na aeronave tal, tal, tal.

O recorte acima aponta para outra troca pronominal; afinal foi o rapaz da imigração quem lhe falou sobre dar outra passagem, mas ela coloca em sua fala: Eu falei: ai meu Deus! Vou te dar outra passagem, você vai embarcar agora, na aeronave tal, tal, tal.

A confusão no uso dos pronomes, aspecto importante da linguagem, pode apontar para o efeito, sobre a língua estrangeira, de marcas primitivas vividas com a língua fundadora, como coloca Gasparini (2010b). Investigando o processo de aquisição de linguagem, no que se refere especificamente ao uso dos pronomes, Lemos (1990, p. 10) afirma tratar-se de um longo percurso, o que se justifica pelo fato de ser um processo no qual a criança precisa "descentrar-se de sua própria atividade linguística e objetivar-se como locutor, em oposição ao interlocutor e à posição discursiva correspondente à terceira pessoa”. Para essa autora, o pronome permite identificar o papel discursivo do locutor, como aquele que pode dizer eu, o do destinatário, como você, e o dos não participantes do discurso, como ele/ela. Considerando que os pronomes revelam-se como importantes indícios da conversão do discurso do outro em discurso próprio, eles indicam a separação do eu/você/outros, gerando uma diferenciação do sujeito que fala em relação aos demais. Em trabalho posterior, Lemos (2004, p. 24) retoma a questão dos pronomes e fala sobre sua estabilização: "É o seu estar na língua, submetido às suas condições estruturais, que lhe vai permitir, na fala, fazer circular todos os pronomes na sua efemeridade, pelas várias figurações discursivas: autor, narrador, personagem, locutor, destinatário.”

Retomando o dito de Celina: Ai ele falou assim, eu falei assim: não, não vou aceitar, podemos ver que a palavra seria dele ele falou assim, mas ela toma para si: eu falei assim. Episódios como esse - e como os citados antes - chamam nossa atenção, fornecendo-nos suporte para formularmos as seguintes perguntas: estaria essa confusão pronominal apontando para um momento da fala da criança, quando ela ainda não se assume como eu, como sujeito que fala? Estariam essas trocas e hesitações indicando o retorno de uma marca infantil de não separação entre o eu e o outro, dificultando-lhe tomar a palavra, marca vivida na língua fundadora e que produz efeito sobre a língua estrangeira? Indagamos, também, se os momentos de confusão entre os pronomes eu e ele, em Celina, não estariam indicando o retorno de um momento da fala infantil em que ainda é preciso constituir a exterioridade, a ausência representada por ele, para que o eu-tu se estabilize? 
Nessa direção, convocamos Dufour (2000), segundo quem o ele - considerado, na proposta de Benveniste, como sendo uma forma não pessoal - é o protagonista externo à copresença eu-tu. Coloca, então: "Mas esta copresença é verificada se, e apenas se, a ausência é certificada com exatidão como estando fora de seu campo" (p. 93). Trata-se de uma ausência, de uma exterioridade necessária à constituição da presença: "a prova certa de sua copresença lhe é externa" (p. 93-94). Sobre essa exterioridade, abordaremos o chamado discurso direto, insistentemente presente nos ditos de Celina, do qual recortaremos apenas alguns exemplos:

[...] Aí depois eu acabei de ler, sentei na mesa pra tomarmos o café e ele falou assim pra mim: você leu tudo? Eu falei: sim. E ele falou assim: o que é que você resolveu? Né? Aí eu falei eu falei falei pra ele: eu não vou, eu, eu, eu não... [...]

[...] Menina, eu fiquei ainda mais confusa, eu falei: Meu Deus, o que é que é isso? [...]

[...] E isso me constrange, as pessoas corrigirem me corrigirem, né, a gente, e aí eu falei: não, eu vou aceitar, né, todas as coisas que eles fizerem eu vou aceitar, porque é uma crítica construtiva e eu vou aprender. [...]

Abrimos um parêntese para lembrar que discursos direto e indireto são conceituados na gramática (BECHARA, 2009), levando-se em conta a relação entre falas do narrador e dos personagens, na narrativa. Nessa perspectiva, o discurso direto indica uma distância, tomada pelo narrador, da fala do personagem, como se ele a delimitasse, destacando-a como sendo do outro, ou melhor, demarcando, em tal fala, uma posição de exterioridade, cujas principais marcas são o verba dicendi ${ }^{6}$ e as aspas. Diferentemente, no discurso indireto, a fala do narrador penetra na do personagem, na medida em que esta sofre modificações, em função daquela, como por exemplo, no uso do tempo verbal.

Convocamos, mais uma vez, Lemos (2001) que, ao estudar a estruturação da narrativa na fala infantil, através de episódios de narrativa de uma criança, em estudo longitudinal, referese a um momento em que o discurso direto, por exemplo, tem presença marcante. Os personagens ganham voz e ficam demarcadas as fronteiras entre a fala do personagem e a do narrador cuja fala é introduzida não apenas pela expressão ele falou, mas por: ela fez um pedido, ele perguntou, ele fica bravo. No que concerne ao episódio de um outro momento - que indica uma mudança de posição da criança em relação ao uso de pronomes - essa autora destaca a presença exclusiva do discurso indireto que apaga a voz dos personagens e deixa escutar somente a voz hegemônica do narrador, que coloca em cena o autor.

Pelo que foi posto, ao que parece, estamos diante de um impasse colocado pelo discurso de Celina sobre sua dificuldade com a língua inglesa. Em outras palavras: de um lado, aparece uma confusão e hesitação entre o eu e o ele, indicando lugares de retorno de um momento da fala infantil em que a exterioridade do ele ainda não se constituiu; de outro lado, o discurso direto - que representa a exterioridade do personagem em relação ao narrador -, faz-se presente naqueles fragmentos de discurso. Lembremos, entretanto, que não se trata, simplesmente, da presença do discurso direto o qual convive com o discurso indireto, demarcando as falas de

\footnotetext{
${ }^{6}$ Palavras que introduzem a fala dos personagens, como: ele falou, ele disse, ele perguntou, ele exclamou etc.
} 
personagens em narrativas. O que nos causou estranhamento foi a insistência, a presença maciça desse tipo de discurso, ao lado da escassez do discurso indireto ${ }^{7}$ e acrescida da constatação de que o verba dicendi se reduz a falar (eu falei, ele falou ...). Retornemos ao estudo de Lemos (2001) que se refere à constituição do discurso direto, na narrativa infantil, como um momento em que ocorre a separação entre o narrador (a criança) e a voz do personagem cuja exterioridade é demarcada. No entanto, lembremos, para que essa separação, essa exterioridade se consolide, é preciso que apareça - e passe a dominar -, na narrativa infantil, o discurso indireto, indicando, ao mesmo tempo, o apagamento da voz do personagem e o aparecimento do narrador (a criança) como autor, como aquele que toma a palavra. Assim, no discurso indireto, o dito do narrador assimila o dito do personagem; mas, concomitantemente, marca a separação entre os dois - que não se confundem -, assegurando, portanto, a exterioridade dos ditos do personagem. É nesse sentido que poderíamos dizer que o discurso indireto - cuja escassez foi notada no relato de Celina sobre suas dificuldades com o inglês -, consolidaria a exterioridade constitutiva do ele como prova da co-presença eu-tu.

Para finalizar essa discussão, indagamos se a insistência do discurso direto não estaria também apontando para um retorno de marcas de dificuldade implicada na separação entre o eu e o outro, na língua materna, produzindo efeito sobre a língua estrangeira.

\section{Considerações finais}

É importante registrar que não tivemos a pretensão de apresentar respostas às várias questões levantadas neste artigo, mas apenas tentamos dar indicações do que poderia emergir da história de Celina, ao enfrentar a difícil experiência com a língua estrangeira.

Na perspectiva aqui assumida, lembremos que o espelhamento entre a fala da mãe e a fala infantil, num momento inicial da aquisição da língua materna, implica a não separação da criança em relação ao outro (a mãe). Como consequência, é preciso que ela se separe desse outro, para que venha a se constituir como sujeito falante. No entanto, conforme foi colocado, tal separação gera angústia, ligando-se ao afeto de medo e, por isso, é recalcada, submetendo-se à outra face do recalque, isto é, o seu retorno em algumas situações vividas pelo sujeito. Uma dessas situações, a partir de propostas de autores aqui tomadas como fundamento, seria o confronto com a língua estrangeira, considerando a singularidade dos sujeitos. Assim, o medo (da separação) estaria ligado ao recalque (e ao retorno do recalcado) no que toca a relação entre língua materna e língua estrangeira. Levando em conta as severas dificuldades vividas por Celina no seu processo de aquisição da língua inglesa, em situação muito propícia de imigração, indicamos, em seu discurso sobre tais dificuldades, algumas marcas do medo de se separar da língua materna e seu efeito - em termos de obstáculos - sobre a língua estrangeira: a insistência do significante medo em seu deslizamento para outros significantes; as contradições - implicadas em um movimento na direção de falar o inglês e, ao mesmo tempo, de buscar, com mais intensidade, o familiar da língua materna; e ainda as questões colocadas por uma confusão pronominal e pela proliferação do discurso direto. Essas marcas fundamentaram, portanto, as

\footnotetext{
${ }^{7}$ Convém notar que o discurso indireto somente aparece quando Celina está falando apenas dela, usando eu... eu...
} 
indagações formuladas, neste artigo, na direção da proposta de que elas estariam indicando um retorno da vivência infantil de separação da língua materna, com o medo que acompanha tal separação.

Celina se vê diante da necessidade de deslocar-se de sua posição de falante apenas do português, para ocupar a posição de falante também do inglês, obviamente sem perder sua condição de sujeito constituído na língua materna. Geralmente, esse deslocamento vem atrelado a vários conflitos de diferentes ordens, o que nos faz lembrar Milner (2018), para quem a língua materna é inaugural e marca o sujeito de forma definitiva, marca que traz à cena, conforme ressalta Revuz (2016), o laço específico mantido com essa língua fundadora.

Antes de finalizar, é importante indicarmos questões - que emergiram do discurso de Celina - sobre o corpo, não tendo sido, porém, abordadas, pela necessidade de selecionarmos e privilegiarmos algumas questões, considerando o espaço de que se dispõe em um artigo. Essa seleção não implica, entretanto, que desconheçamos a importância do corpo no que toca nosso objetivo. Celina se aposentou em virtude de sua obesidade e, em alguns momentos, refere-se ao excesso de peso e às dificuldades e sofrimento que já lhe causou. Lembremos que ela apresentou marcas no corpo - aftas externas - quando da situação que considerou a mais difícil diante do "não saber falar inglês". Indagamos então: qual o lugar ocupado pelo corpo, no discurso de Celina sobre suas dificuldades com a língua estrangeira? Qual o papel dos sons, do ritmo e da melodia da língua materna nessas dificuldades? E ainda: os conflitos, na relação entre as línguas materna e estrangeira, que se mostram nesse discurso, não estariam indicando, em última análise, um retorno de marcas inscritas, no corpo, pela língua inaugural?

Trata-se de questões que, provavelmente, abrirão caminho para outro trabalho, privilegiando o corpo na relação entre língua materna e língua estrangeira, o que contribuirá, sem dúvida, para a continuidade da discussão aqui iniciada.

\section{Referências}

BECHARA, E. Moderna gramática portuguesa, 37. ed. Rio de Janeiro: Nova Fronteira, 2009.

CORACINI, M. J. Identidade e discurso: (Des)construindo subjetividades. Campinas/Chapecó: Ed. da Unicamp/Argos, 2003.

CORACINI, M. J. A celebração do outro, arquivo, memória e identidade: línguas (materna e estrangeira), plurilinguismo e tradução. São Paulo: Mercado das Letras, 2007.

DUFOUR, D. R. Os mistérios da trindade. Rio de janeiro: Companhia de Freud, 2000.

FREUD, S. O recalque, 1915. In: Escritos sobre a psicologia do inconsciente. 1856-1939. Tradução de Luiz Alberto Hanns. Rio de Janeiro: Imago, 2004.

FREUD, S. Inibição, sintoma e medo. (1856-1939). Tradução de Renato Zwick. Porto Alegre, RS: L\&PM, 2018.

GARCIA-ROZA, L. A. Freud e o inconsciente. 24. ed. Rio de Janeiro: Jorge Zahar Ed., 2009.

GASPARINI, D. S. R. Como a língua materna afeta o sujeito na aprendizagem de línguas estrangeiras? Entremeios: revista de estudos do discurso. v.1, n.1, pp. 1-10, 2010a. 
GASPARINI, D. S. R. Reflexões sobre língua materna e língua estrangeira a partir da incidência de Lalangue. 2010. Dissertação (Mestrado em Linguística Aplicada) - Universidade Estadual de Campinas. Campinas, 2010b. Disponível em: http://repositorio.unicamp.br/handle/REPOSIP/269771. Acesso em: 23 set. 2018.

HANNS, L. Dicionário comentado do alemão de Freud. Rio de Janeiro: Imago, 1996.

LACAN, Jacques. O Seminário, livro 20: Mais, ainda. Tradução de M. D. Magno. Rio de Janeiro: Jorge Zahar Editor, 1985.

LEMOS, C. T. G. Uma abordagem sócio-construtivista da aquisição da linguagem: um percurso e muitas questões. Palestra apresentada no Congresso de Fonoaudiologia de Santa Maria, RS. 1990.

LEMOS, C. T. G. Sobre o estatuto linguístico e discursivo da narrativa na fala da criança. Linguística, São Paulo, v.13, pp. 23-60, 2001.

LEMOS, C. T. G. Sobre os pronomes pessoais na fala da criança. Letras de Hoje. Porto Alegre, v. 39, n. 3, pp. 9-25, 2004.

LEMOS, C. T. G. Da angústia na infância. Revista Literal. Campinas, v. 10, pp. 117-126, 2007.

MELMAN, C. Imigrantes. Incidências subjetivas das mudanças de língua e país. Tradução de Rosane Pereira. Contardo Calligaris (org.) São Paulo: Escuta, 1992.

MILNER, J. C. O Amor da Lingua. Tradução de Paulo Sérgio Souza Júnior. São Paulo: Unicamp, 2018.

MORAES, M. R. S. Materna/Estrangeira: o que Freud fez da lingua. 1999. Tese (Doutorado em Linguística) - Universidade Estadual de Campinas, Campinas: 1999. Disponível em: http://repositorio.unicamp.br/bistream/REPOSIP/271090/1/Moraes_MariaRitaSalzano_D.p df. Acesso em: 12 out. 2018.

REVUZ, C. A língua estrangeira entre o desejo de um outro lugar e o risco do exílio. In: SIGNORINI, I. (org.) Lingua(gem) e identidade: elementos para uma discussão no campo aplicado. Campinas, SP: Mercado das Letras; São Paulo: Fapesp, 1998. 2a ed. 2016.

SERRANI-INFANTE, S. Identidade e segundas línguas: as identificações no discurso. In: SIGNORINI, Inês (org.). Lingua(gem) e identidade: elementos para uma discussão no campo aplicado. Campinas: Mercado das Letras; São Paulo: FAPESP, 1998. 2 ed. 2016.

VILAR DE MELO, M. F. Le lien entre la langue maternelle et la parole symptomatique dans les aphasies: quelques questions. In: 15th. International Pragmatics Conference, 15, 2015, Antuérpia. Anais. Universidade da Antuérpia.

Recebido em: 14/09/2019

Aceito em: 07/11/2019 